\section{P.E.R \\ Pioneer in peer-reviewed, open access online law publications}

Author

Hanneretha Kruger

Affiliation

University of South Africa

Email krugejm1@unisa.ac.za

Date of submission

2 March 2017

Date published

26 September 2018

Editor Prof C Rautenbach

How to cite this article

Kruger $\mathrm{H}$ "The Protection of

Children's Right to Self-

Determination in South African Law with Specific Reference to Medical Treatment and Operations" PER / PELJ 2018(21) - DOI

http://dx.doi.org/10.17159/1727-

3781/2018/v21i0a4609

\section{Copyright}

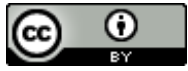

DOI

http://dx.doi.org/10.17159/17273781/2018/v21i0a4609

\begin{abstract}
The Children's Act 38 of 2005 provides that children over the age of 12 years can consent to their own medical treatment or that of their children, provided they are of sufficient maturity and have the mental capacity to understand the benefits, risks, social and other implications of the treatment (section 129(2)). The predecessor of the Children's Act set the age at which children could consent to medical treatment at 14 years, and no maturity assessment was required (Child Care Act 74 of 1983 section 39(4)). Children over the age of 12 years can consent to the performance of surgical operations on themselves or their children, provided that they have the level of maturity described above and they are duly assisted by their parents or guardians (Children's Act section 129(3)). Before the Children's Act came into operation, the Child Care Act allowed children over the age of 18 to consent to their own operations (section 39(4)). Neither a maturity assessment nor parental assistance was required. (Note that when the Child Care Act was in operation the majority age was still 21 years.) In this article the question is considered if the relaxation of the limitations on children's capacity to consent to medical treatment and surgical operations in the Children's Act recognises the right of children to make independent decisions without the assistance of their parents or guardians or other substitute decision-makers. Firstly the article investigates the theoretical foundations of the protection of children's rights, particularly their autonomy rights. Secondly the meaning of the concept "competence" in medical decisionmaking and the related concept of "informed consent" are discussed. Thirdly some developmental and neuroscientific research on children's decisionmaking capacities and how they influence children's competence to give consent valid in law are highlighted. Fourthly possible legal foundations for the protection of children's right to self-determination in medical decision-making are sought in the Constitution and international and regional human rights treaties. Finally the relevant provisions of the Children's Act are examined in order to ascertain whether children's right to self-determination is sufficiently protected in South African law.
\end{abstract}

\section{Keywords}

Children's autonomy; children's right to self-determination; children's competence; adolescent capacity; informed consent; consent to medical treatment by children; consent to surgical operations by children. 


\section{Introduction}

Adults of sound mind have control over their own bodies, and can consent to or refuse medical treatment. In Castell $v$ De Greeff ${ }^{1}$ a Full Bench of the Cape Provincial Division of the Supreme Court (as it was then known) held that a medical practitioner has a legal duty to obtain the patient's informed consent to any medical intervention. The court gave content to the concept informed consent, following a patient-focused approach that recognised the fundamental rights of autonomy and self-determination that were becoming increasingly important in South Africa. ${ }^{2}$

In general, a minor ${ }^{3}$ who has never been married has no capacity to perform a juristic act without the assistance of his or her parents or guardian unless such a juristic act confers only benefits on the minor. An important objective for the limitation of the capacity of children to perform juristic acts is to protect them from their own immaturity of judgment. ${ }^{4}$ As far as medical decision-making in particular is concerned, children were at common law regarded as incompetent to consent to medical treatment and operations, and their parents had to consent on their behalf. ${ }^{5}$ Gradually these limitations on the capacity of children were relaxed. In terms of the Child Care Act 74 of 1983, children over the age of 14 were competent to consent to the medical treatment of themselves or their children without the assistance of their parents or guardians, and children ${ }^{6}$ over the age of 18 years were competent to consent to their own operations without such assistance. ${ }^{7}$ The Choice on Termination of Pregnancy Act 92 of 1996 allows a girl of any age who has the intellectual and emotional capacity for informed consent to consent to the termination of her pregnancy without parental assistance. ${ }^{8}$ The Children's Act 38 of 2005 lowered the age at which children can validly consent to medical treatment to 12 years, provided they are of sufficient maturity and have the mental capacity to understand the benefits, risks,

Hanneretha Kruger. Blur LLB (Free State) LLD (Unisa). Professor of Private Law, University of South Africa. Email: krugejm1@unisa.ac.za.

Castell v De Greeff 19944 SA 408 (C) (hereafter Castell).

Castell 425-426.

A child below the age of 18 years (s 17 of the Children's Act 38 of 2005). This provision lowered the age of majority in South Africa from 21 to 18 years. The Children's Act also repealed the Age of Majority Act 57 of 1972 in its totality.

$4 \quad$ Cockrell "Capacity to Perform Juristic Acts: Contracts" 756 et seq; Heaton Law of Persons 79 et seq; Himonga and Cooke 2007 IJCR 326, 338.

$5 \quad$ Boberg Persons and Family 643 contra Strauss Doctor, Patient and the Law 171. Also see Ngwena 1996 Acta Juridica 140.

$6 \quad$ Note that when the Child Care Act was in operation the age of majority was still 21 years in terms of $s 1$ of the Children's Status Act 82 of 1987. The age of majority was lowered to 18 years on 1 July 2007 by s 17 of the Children's Act.

7 Section 39(4) of the Child Care Act 74 of 1983.

8 Section 5(1)-(3) read with the definition of "woman" in $s 1$ of the Choice on Termination of Pregnancy Act 92 of 1996. 
social and other implications of the treatment. ${ }^{9}$ The Act further allowed children older than 12 years to consent to an operation, provided they are of sufficient maturity and have the mental capacity to understand the benefits, risks, social and other implications of the operation, and provided they are duly assisted by their parents or guardians. ${ }^{10}$

The gradual relaxation of the limitations on children's capacity to consent to certain juristic acts can be attributed to a number of factors. The first is the "global re-ordering of the parent-child relationship" coupled with the recognition of the child as a potentially autonomous person, depending on the task at hand and the child's age and level of maturity. ${ }^{11}$ The second factor, closely related to the first, is the children's rights movement. ${ }^{12}$ Thirdly, this trend is the result of extensive research on children's levels of maturity. ${ }^{13}$ A final contributing factor is the introduction of the Bill of Rights in the Constitution of the Republic of South Africa, 1996 (the Constitution) (which inter alia entrenches the rights to equality, human dignity, privacy, freedom and security of the person, and the rights of the child), and the ratification by South Africa of various international and regional treaties on the rights of children. ${ }^{14}$

The question arises whether the relaxation of the limitations on children's capacity to consent reaches far enough to include the recognition of the right of children to self-determination ${ }^{15}$ in medical decision-making; in other words their right to make medical decisions independently, without the assistance of their parents or guardians or other substitute decision-makers. This article will attempt to answer this question. ${ }^{16}$

The article begins with an investigation of the theoretical foundations of the protection of children's autonomy. This is followed by a discussion of the meaning of the concept "competence" in medical decision-making and the related concept of informed consent. After that, developmental and neuroscientific research on children's decision-making capacities and its influence on children's competence to give consent valid in law is analysed.

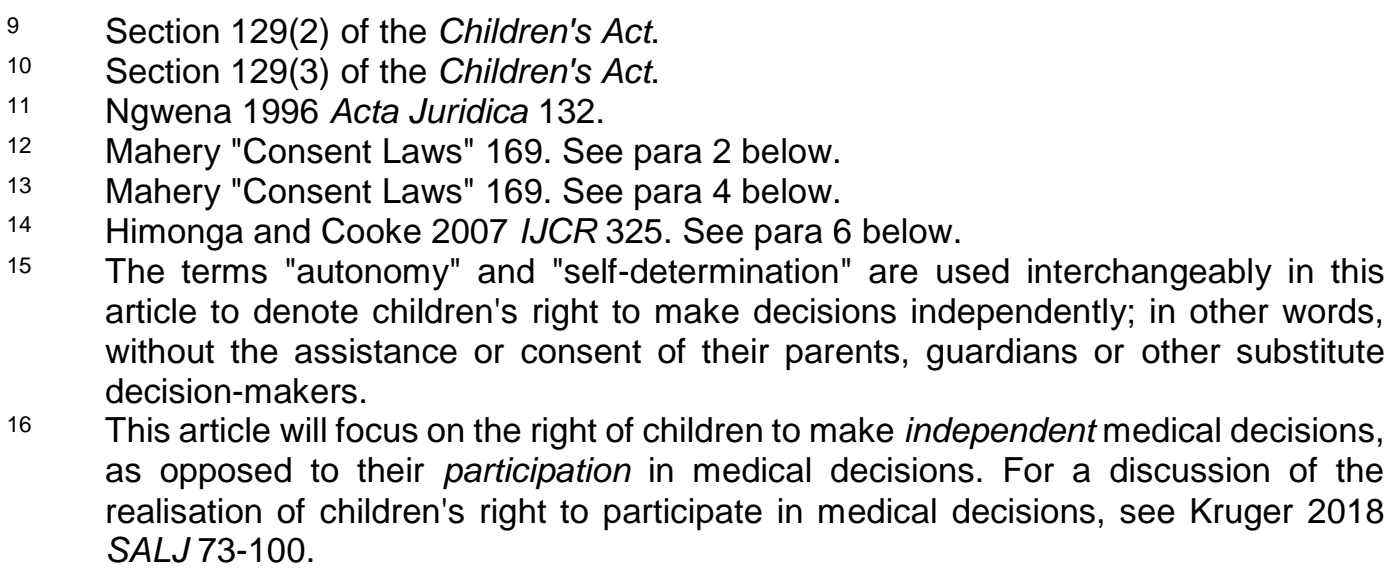
article to denote children's right to make decisions independently; in other words, without the assistance or consent of their parents, guardians or other substitute decision-makers.

16 This article will focus on the right of children to make independent medical decisions, as opposed to their participation in medical decisions. For a discussion of the realisation of children's right to participate in medical decisions, see Kruger 2018 SALJ 73-100. 
In the section that follows I will determine whether the Constitution and international and regional human rights treaties provide a legal basis for protecting children's right to self-determination in medical decision-making. Lastly certain provisions dealing with consent to medical decision-making by children are examined to determine whether the right to selfdetermination is sufficiently protected in South African law. ${ }^{17}$

\section{The protection of children's autonomy: the theoretical foundations}

The notion that children have autonomy worthy or protection had its origin in the children's rights movement. ${ }^{18}$ The late nineteenth ${ }^{19}$ and early twentieth century marked the beginning of the "child-saving" movement. ${ }^{20}$ During this period, what is usually termed children's rights is essentially a concern with protecting children rather than their rights. The distinction between "protecting children and protecting children's rights" is drawn by Farson. ${ }^{21}$ The two approaches to the protection of the rights of children, namely the "nurturance" and "self-determination" approaches, can be recognised in Farson's distinction. In terms of the nurturance approach, children are given "what's good for them", whereas they are given "the right to decide what's good for themselves" in terms of the self-determination approach. ${ }^{22}$ This distinction is encountered often in the literature on children's rights, regardless of the differences in the terminology used. The terms "child liberators" and "child savers" were coined by Coons and Mnookin, ${ }^{23}$ whereas Bainham uses the terms "protectionist" and "liberationist" schools. ${ }^{24}$

At the extreme end of the liberationist school (which contends that children should enjoy adult freedoms) one finds scholars like Holt and Farson. Teacher and author John Holt argued that, regardless of their age, children should have the right to work for money and choose their education. ${ }^{25}$

17 The article will focus on consent to medical treatment and surgical operations by minors as regulated by s 129 of the Children's Act. Due to space constraints, I will not consider the numerous other medical decisions that could involve minors, such as termination of pregnancy in terms of the Choice on Termination of Pregnancy Act. On children's rights theory see in general Kruger Judicial Interference with Parental Authority ch 8; Kruger 2006 THRHR 436 et seq. Freeman Rights and Wrongs 18 shows that the beginnings of a children's rights movement can be traced back to the middle of the nineteenth century. An article entitled "The Rights of Children" appeared as early as June 1852. Freeman Rights and Wrongs 18, referring to the work by Platt entitled The Child Savers: The Invention of Delinquency. Farson Birthrights 165, as cited by Freeman 1980 CLP 17.

Freeman 1980 CLP 15, 17.

Coons and Mnookin "Towards a Theory of Children's Rights" 391-392.

Bainham Children 98-99.

Cited by Wald 1979 UCDLR 257. 
Psychologist Richard Farson takes this a step further by arguing that children's rights can be realised only when all children have total selfdetermination in all aspects of life. In his view, self-determination is at the heart of "children's liberation".26 These scholars base their theories partly on the work of Ariès. ${ }^{27}$ They contend that, since at earlier stages of history children were not treated differently from adults, the conclusion is warranted that children today should be treated like adults. ${ }^{28}$

Some authors argue that the view of the liberationists that children should enjoy adult freedoms does not take cognisance of the physical and mental differences between adults and children as far as development, knowledge, skills, behaviour, and their dependence on adults are concerned. In Freeman's words, "the assertion of the irrelevance of age does not square with either our knowledge of biology or economics". 29

As will be shown below, there is a unique interaction between the nurturance and autonomy approaches to the protection of children's rights. Many of the rights accorded to children (eg the right to protection) have no autonomy element. When dealing with young children it may be much more important to acknowledge nurturance rights than to acknowledge autonomy rights. Autonomy rights become more meaningful as children grow up. While growing up children become less dependent and more likely to take responsibility for their own actions, a capacity that should be acknowledged and encouraged. However, as Freeman warns, a young child who is denied the protection of nurturance rights may never reach the stage where he or she is in a position to claim the autonomy rights advocated by the liberationists. ${ }^{30}$ It is therefore important to protect both nurturance and autonomy rights.

In Gillick v West Norfolk and Wisbech Area Health Authority and the DHSS ${ }^{31}$ the House of Lords recognised this so-called "maturation factor". In 1980 the British Department of Health and Social Security (as it was then known) issued a notice authorising doctors to give contraceptive advice or treatment to girls younger than 16 without the knowledge or consent or their parents. Victoria Gillick, a Roman Catholic mother of five daughters younger than 16, sought assurance from her area health authority that none of her daughters

\footnotetext{
$26 \quad$ Cited by Wald 1979 UCDLR 257.

27 Ariès Centuries of Childhood.

28 Freeman Rights and Wrongs 13.

29 Freeman 1980 CLP 17. Also see Coons and Mnookin "Towards a Theory of Children's Rights" 392; Fortin Children's Rights 6; Human 2000 THRHR 395.

$30 \quad$ Freeman 1980 CLP 17; Freeman 1992 IJLPF 59.

31 Gillick $v$ West Norfolk and Wisbech Area Health Authority and the DHSS 19853 All ER 402 (hereafter Gillick). See, in general, Bainham Children 346 et seq; Eekelaar 1986 LQR 4 et seq; Eekelaar 1986 OJLS 177 et seq; Human 2000 Stell LR 71 et seq; Robinson 1993 TRW 52 et seq.
} 
would receive such advice or treatment without her consent. When she did not get an acceptable response from the health authority she applied for a declaration that the advice in the circular was unlawful as it unjustifiably interfered with her parental authority. She eventually lost her case by means of a 3-2 majority in the House of Lords. ${ }^{32}$

In the majority decision Lord Scarman held that children under 16 acquired the understanding and intelligence needed to give valid consent, not by virtue of age alone, but when "[they reach] a sufficient understanding and intelligence to be capable of making up [their own minds] on the matter requiring decision". ${ }^{33}$ This test allows for an individualistic assessment of a particular child's level of maturity and intellectual ability. ${ }^{34}$

Lord Scarman explicitly found that parental authority was not absolute. He held that parental rights (including the right to decide on medical treatment on behalf of a child) exist only for as long as they are needed to protect the child. ${ }^{35}$ When the child acquires the capacity to make his or her own decisions, parental rights come to an end. ${ }^{36}$

In my view the significance of Gillick is twofold. Firstly, Gillick recognised the fact that childhood is a process of continuous change which takes place as the child develops from newborn to adolescent and eventually adult. Freeman calls childhood a "developmental trajectory" through which all of us pass. ${ }^{37}$ During this process of change, the child's capacity for rational thought gradually develops. As the child matures, the dynamics of the concept parental authority evolve, from total control initially to little more than advice later on.

Secondly, Gillick confirmed that the "nurturance" and "self-determination" approaches to the protection of children's rights are not mutually exclusive. The stage of development of the child should determine the approach to be followed. If the child is too young to have the capacity for rational thought, the "nurturance" approach should be favoured. As the child develops the capacity for rational thought, the "self-determination" approach should become more important. Freeman's call for a via media approach is therefore supported. In his words: ${ }^{38}$

32 Gillick $v$ West Norfolk and Wisbech Area Health Authority and the DHSS 19853 All ER 402. See further Bainham Children 346; Eekelaar 1986 LQR 4.

33 Gillick 422a.

34 Gillick 424b-d.

35 Gillick 421e.

$36 \quad$ Gillick 423j.

37 Freeman 1992 IJLPF 66.

$38 \quad$ Freeman "Limits of Children's Rights" 39. 
To take children's rights seriously requires us to take seriously nurturance and self-determination, demands of us that we adopt policies, practices and laws which both protect children and their rights.

\section{3 "Competence" in medical decision-making}

\subsection{The meaning of the concept "competence"}

To give meaning to the concept "competence" and to determine the relevant standards for assessing a child's competence or maturity, it is necessary to look for answers in social science theory. A good starting point is Buchanan and Brock's work on surrogate decision-making in the health-care setting, Deciding for Others. ${ }^{39}$ Buchanan and Brock argue that competence should be understood as decision-making capacity. However, they add that the concept of decision-making capacity is incomplete until the nature of the choice and the conditions under which it has to be made are specified. Competence is therefore "decision-relative, not global". ${ }^{40} \mathrm{~A}$ person may be competent to make a particular decision at a particular time and under particular circumstances, but incompetent to make another decision, or the same decision, under different circumstances. A determination of competence, according to Buchanan and Brock, is a determination of a particular person's capacity to make a particular decision at a particular time and under specified conditions. ${ }^{41}$

Further, different decision-making tasks require different capacities of the decision-maker. Even if only medical treatment decisions are considered, the complexity of the information that is relevant to a particular treatment decision and therefore of the factors that must be understood by the decision-maker varies substantially. ${ }^{42}$

\subsection{The capacities needed for competence}

Although different decisions require different capacities from decisionmakers, it is possible to generalise about the required capacities. Buchanan and Brock identify three capacities: the capacity for understanding and communication, the capacity for reasoning and deliberation, and a set of values or a concept of what is good. ${ }^{43}$

First, understanding and communication encompass the various capacities that allow a person to become informed about the particular treatment, and to express a choice about the treatment. These include the linguistic,

\footnotetext{
Himonga and Cooke 2007 IJCR 340.

Buchanan and Brock Deciding for Others 18.

Buchanan and Brock Deciding for Others 18.

Buchanan and Brock Deciding for Others 21.

Buchanan and Brock Deciding for Others 23.
} 
conceptual and cognitive abilities necessary for receiving and understanding the relevant information. In general terms, the information will concern the nature of and reasons for the treatment. Specifically, the information will include the patient's diagnosis; the different prognoses if different treatment alternatives (including the alternative of no treatment) are available, including the significant risks and expected benefits; and the medical practitioner's recommendation regarding treatment. ${ }^{44}$

Understanding is not only a formal or abstract process, but also requires the ability to appreciate the nature and meaning of potential alternatives, and to integrate this appreciation into the decision-making process. Buchanan and Brock indicate that young children often lack this level of understanding due to their lack of relevant life experience. ${ }^{45}$

Secondly, competence requires capacities for reasoning and deliberation. Sufficient short-term memory capacity should be present so that the decision-maker can retain the information during the period needed to make the decision, which can sometimes be protracted. Reasoning and deliberation require the capacities to draw inferences about the consequences of making a particular decision and to compare alternative outcomes. ${ }^{46}$

Finally, a competent decision-maker requires a consistent and stable set of values or a concept of what is good. This enables the decision-maker to evaluate particular outcomes and decide if they are beneficial or harmful, and assign different relative importance to them. ${ }^{47}$

\subsection{The link between competence and informed consent}

The concepts of competence and informed consent are linked. The doctrine of informed consent requires the free and informed consent of a competent patient before medical procedures can be performed. Possession of the competence to make decisions is therefore one of the key requirements for informed consent in medical decision-making. The other requirements are that the decision should be voluntary and that appropriate information should be provided in a form that the patient can understand. ${ }^{48}$ It goes without saying that a child who does not have the maturity to understand the nature and extent of the harm or risk attached to the proposed medical

$44 \quad$ Buchanan and Brock Deciding for Others 23

45 Buchanan and Brock Deciding for Others 24.

46 Buchanan and Brock Deciding for Others 24-25.

$47 \quad$ Buchanan and Brock Deciding for Others 25.

48 Buchanan and Brock Deciding for Others 26; Himonga and Cooke 2007 IJCR 340; Scott, Reppucci and Woolard 1995 Law \& Hum Behav 223-224. On informed consent, see in general Van Oosten Doctrine of Informed Consent. Also see Neethling and Potgieter Law of Delict 111 et seq; McQuoid-Mason 2010 SAMJ 213. 
intervention would not be able to give informed consent to such an intervention.

In Castell $v$ De Greef ${ }^{49}$ the court provided guidance on the level of disclosure that is necessary to achieve informed consent. It was held that for consent to be informed, the patient must fully appreciate the nature and extent of the harm or risk to which he or she is consenting. The medical practitioner is under a duty to warn the patient of a material risk inherent in the proposed treatment. In the words of Ackermann J:50

[A] risk [is] material if, in the circumstances of the particular case: (a) a reasonable person in the patient's position, if warned of the risk, would be likely to attach significance to it; or (b) the medical practitioner is or should reasonably be aware that the particular patient, if warned of the risk, would be likely to attach significance to it.

The National Health Act 61 of 2003 regulates the level of disclosure to be provided to users ${ }^{51}$ by health care providers. The Act places an obligation on every health care provider to inform a user of his or her health status, except where there is substantial evidence that the disclosure of the user's health status would be contrary to his or her best interests (the so-called "therapeutic privilege"). The user must also be informed of the range of diagnostic procedures and treatment options generally available to the user and the benefits, risks, costs and consequences generally associated with each of these options. Finally, the health care provider must inform the user of his or her right to refuse health services, as well as the implications, risks and obligations of the refusal. Where possible, the health care provider must inform the user in a language that he or she understands and in a manner that takes into account the user's level of literacy. ${ }^{52}$ The Act further stipulates that a health service may not be provided to a user without the user's informed consent, ${ }^{53}$ and a health care provider must take all reasonable steps to obtain the user's informed consent. If informed consent is given by a person other than the user, the person giving consent must, if possible,

$49 \quad$ Castell $v$ De Greeff 19944 SA 408 (C).

$50 \quad$ Castell 426.

$51 \quad$ "User" is defined as a person receiving treatment in a health establishment, including receiving blood or blood products, or using a health service (National Health Act 61 of 2003 s 1). If the user is "below the age contemplated in section 39(4) of the Child Care Act, 1983, 'user' includes the child's parent or guardian or another person authorised by law" to act on behalf of the child. In view of the fact that the Child Care Act was repealed on 1 April 2010, an amendment of this definition is long overdue.

52 Section 6 of the National Health Act.

53 Section 7(1) of the National Health Act. In some instances health services may be provided to a user without his or her informed consent, eg if the user is unable to give informed consent and such consent it given by a person mandated by the user in writing to provide consent on his or her behalf, or authorised to give consent in terms of any law or court order $(s 7(1)(a))$, or if failure to treat the user, or a group of people which includes the user, will result in a serious risk to public health $(s 7(1)(d))$. 
consult the user before giving the required consent. A user who is capable of understanding must be informed, as required by section 6 , even if he or she lacks the legal capacity to give informed consent. ${ }^{54}$ Thomas $^{55}$ indicates that the standard of disclosure provided for in the Act goes further than the common law, although the retention of the therapeutic privilege detracts from requiring full disclosure. ${ }^{56}$

The provisions of the National Health Act relating to informed consent are further strengthened by the Children's Act, which protects the right of children to access to information on health care. This includes information on the promotion of health and the treatment of ill-health and disease, sexuality and reproduction. ${ }^{57} \mathrm{~A}$ child also has the right to have access to information regarding his or her health status, including the causes and treatment of his or her health status, and the right to confidentiality regarding his or her health status. ${ }^{58}$ The information provided to children must be relevant and in a format accessible to children, and due consideration must be given to the needs of disabled children. ${ }^{59}$

\section{Developmental and neuroscientific research on children's decision-making capacities}

A discussion of the decision-making capacities of children, particularly adolescents, ${ }^{60}$ would be incomplete without reference to scientific research on this topic. For decades it has been accepted that the answers to questions about children's decision-making capacities lie in social science, particularly developmental psychology. In the literature on developmental psychology two broad categories are distinguished. Some attribute youthful immaturity to cognitive differences between adolescents and adults (in other words, deficiencies in the way adolescents think), whereas others attribute immaturity to psychosocial differences (in other words, deficiencies in adolescents' social and emotional capability). ${ }^{61}$ Caufmann and Steinberg submit that "judgment" (their term for the process of decision-making) is

\footnotetext{
54 Section 8(2) of the National Health Act.

55 Thomas 2007 SALJ 208.

56 Thomas 2007 SALJ 208-209.

57 Section 13(1)(a) of the Children's Act.

58 Section 13(1)(b)-(d) of the Children's Act.

59 Section 13(2) of the Children's Act.

60 Social scientists who study adolescence usually differentiate three stages: early adolescence, which covers the period from about age 11 to age 14, middle adolescence, from about age 15 to age 18, and late adolescence (sometimes called youth), from about age 18 to age 21 (Steinberg Adolescence 5). The World Health Organisation defines adolescence as "being between the ages of 10 and 19 years" (WHO Health of Young People 1). 
neither exclusively cognitive nor exclusively psychosocial, but the "byproduct of both sets of influences". 62

Many studies based on the cognitive contributors to decision-making found few differences between adults and mid-adolescents. ${ }^{63}$ However, in 2000 Caufmann and Steinberg reported on a study focused on the psychosocial contributors to decision-making (responsibility, perspective and temperance). ${ }^{64}$ They found that the period between 16 and 19 years "marks an important transition point in psychosocial development that is potentially relevant to debates about the drawing of legal boundaries between adolescence and adulthood". 65 The authors came to the conclusion that adolescents are less psychosocially mature than adults in ways that affect their decision-making in antisocial situations, which in their view supports the argument that juvenile offenders may have diminished responsibility. ${ }^{66}$

Previously it was believed that the human brain had matured by the time the child reached twelve years of age. However, relatively recent studies based on MRI scans of children's neurological development show that physical brain development and cognitive functioning continue after puberty and into the early twenties. The frontal lobe is the last area of the brain to develop. ${ }^{67}$ The prefrontal cortex, situated within the frontal lobe, does not complete its development until early adulthood. The prefrontal cortex is the area of the brain where the highest level of thinking occurs, and is associated with cognitive abilities like decision-making, risk assessment, and the ability to judge future consequences. ${ }^{68}$ These neuroscientific findings have led the

62 Caufmann and Steinberg 2000 Behav Sci Law 743.

$63 \quad$ Grisso ans Vierling 1978 Prof Pshychol 412 et seq. Also see Hartman 2000 Hastings LJ 1318-1320; Hartman 2002 AJLM 423; McCabe 1996 J Pediatr Psychol 507-508; Ngwena 1996 Acta Juridica 136-138; Scott, Reppucci and Woolard 1995 Law \& Hum Behav 222; Spear Behavioral Neuroscience of Adolescence 136-139; Steinberg and Meyer Childhood 452.

$64 \quad$ Caufmann and Steinberg 2000 Behav Sci Law 741.

65 Caufmann and Steinberg 2000 Behav Sci Law 756.

66 Caufmann and Steinberg 2000 Behav Sci Law 759.

67 The composition of the frontal lobe changes drastically during adolescence. First, the adolescent brain forms large amounts of neurons (grey matter). The grey matter is then rapidly pruned to eliminate unnecessary synapses, making the neural connections more efficient. While this pruning is taking place, the brain's circuitry is insulated with white fatty tissue, a process called myelination. This process ensures that signals move quicker and more efficiently through the brain. MRI studies show a significant increase in myelin from ages 12-16 to 23-25 (Arshagouni $2006 \mathrm{~J}$ Health Care L \& Pol'y 347-349; Binford 2012 Article 40 4; Blakemore and Choudhury 2006 J Child Psychol Psychiatry 296 et seq; Delmage 2013 Youth Justice 105-107). seq; Blakemore and Choudhury $2006 \mathrm{~J}$ Child Psychol Psychiatry 296 et seq; Delmage 2013 Youth Justice 105-107. 
US Supreme Court to strike down a series of sentencing practices involving children, including the death penalty. ${ }^{69}$

An in-depth analysis of the developmental and neuroscientific research on adolescent decision-making capacities falls outside the scope of this article. The purpose of this brief overview is to show that collaboration between science and law is vital for creating legislative policy that takes cognisance of adolescent decision-making capacities. ${ }^{70}$ However, translating neuroscientific research and knowledge into legal constructs is by no means an easy task. ${ }^{71}$ It should be kept in mind that neuroscientific research has only demonstrated associations between brain regions and the developing cognitive functions of adolescents, and care should be taken not to assume a causal relationship between the development of brain regions and cognitive functions in adolescents. ${ }^{72}$

Further, the question arises whether there is a tension between the age at which criminal and civil responsibilities are attained. ${ }^{73} \mathrm{~A}$ finding of incompetence to make one kind of decision may not necessarily translate into incompetence to make decisions in other contexts. ${ }^{74}$ These tensions may exist not only between criminal and civil competences, but also between different kinds of civil competencies, such as different kinds of medical decisions. Is the same level of competency needed to consent to the extraction of a tooth and a liver transplant, for example?

\section{Protecting children's right to self-determination - the legal foundations}

\subsection{The United Nations Convention on the Rights of the Child}

The United Nations Convention on the Rights of the Child (1989) (hereafter the Convention) ${ }^{75}$ acknowledges that the rights of children were not adequately protected in existing human rights treaties and provides international standards to assist state parties in drafting domestic legislation and policy on the areas covered by the Convention. ${ }^{76}$ The fact that a separate treaty was established for children has enabled a wide range of

69 The death penalty for criminal acts committed by children was abolished in Roper $v$ Simmons 543 US 551 (2005). Also see Arshagouni 2006 J Health Care L \& Pol'y 351; Binford 2012 Article 406.

70 Hartman 2002 AJLM 453. Also see Scott, Reppucci and Woolard 1995 Law \& Hum Behav 240.

$71 \quad$ Delmage 2013 Youth Justice 108.

72 Delmage 2013 Youth Justice 105, 108.

73 Delmage 2013 Youth Justice 104.

74 Scott, Reppucci and Woolard 1995 Law \& Hum Behav 225.

75 South Africa ratified the Convention on Youth Day (16 June) in 1995.

76 De Villiers 1993 Stell LR 295-296; Sloth-Nielsen 1995 SAJHR 402. 
children's needs and interests to be articulated. The establishment of a system of implementation will facilitate the development of a child-oriented human rights jurisprudence. ${ }^{77}$

The Committee on the Rights of the Child identified four articles that in their opinion provide "soul" to the Convention, as they represent the value system on which the Convention is based and are central to its interpretation. ${ }^{78}$ Three of these core principles are relevant to this article.

The first core principle is contained in article 3, which sets the best interests of the child standard as a primary consideration in all actions concerning children. Article 3 provides that

[i]n all actions concerning children, whether undertaken by public or private social welfare institutions, courts of law, administrative authorities or legislative bodies, the best interests of the child shall be a primary consideration.

The ascription of due importance to the best interests of the child provides the backdrop against which all the articles in the Convention should be read. ${ }^{79}$ The Convention requires the best interests of the child to be "a primary consideration", as opposed to "the primary consideration". 80 Consequently, when decisions are made regarding the best interests of children, the interests of other parties involved, for example parents and the state, can also be considered. However, these other interests cannot be the only consideration - the best interests of children should be given due consideration. ${ }^{81}$

The second core principle that is relevant to this article is the protection provided in article 12 of the right of children to express their views in proceedings where their interests are at stake. This provision signifies the child-centred approach of the Convention. ${ }^{82}$ This provision, which has been described as the "linchpin" of the Convention, ${ }^{83}$ reflects a paradigm shift in the law's approach to children. ${ }^{84}$ The Convention recognises that the "best interests of the child" is not merely to be gleaned from what adults think is

\footnotetext{
77 De Villiers 1993 Stell LR 296; Sloth-Nielsen 1995 SAJHR 402-403; Van Bueren "United Nations Convention on the Rights of the Child" 210-212.

78 Sloth-Nielsen 1995 SAJHR 408-409.

79 Fortin Children's Rights 38; Sloth-Nielsen 1995 SAJHR 408-409.

$80 \quad$ Also see para 5.2 below.

81 Sloth-Nielsen 1995 SAJHR 408.

82 Sloth-Nielsen 1995 SAJHR 403. Also see Robinson 2002 Stell LR 314; Robinson and Ferreira 2000 De Jure 56.

83 Freeman 1998 IJCR 438.

84 Barratt 2002 THRHR 557.
} 
best for the child, but that children as bearers of rights also have a right to a say in matters affecting their interests. ${ }^{85}$

In terms of article 12(1), state parties must assure to a child who is capable of forming his or her own views the right to express those views freely in all matters affecting the child. The views of the child must be given due weight in accordance with the age and maturity of the child. Article 12(2) affords children an opportunity to be heard in any judicial and administrative proceedings affecting them, either directly or through a representative or appropriate body, in a manner consistent with the procedural rules of national law.

According to the Committee on the Rights of the Child, age alone cannot determine the importance of a child's views, as various factors contribute to the development of a child's capacity to form a view. These include information, experience, environment, social and cultural expectations, and levels of support. As a result, the Committee recommends that the views of the child should be assessed on a case-by-case basis. ${ }^{86}$

Some authors are of the view that the obligation created in article 12 to give the views of children "due weight in accordance with the age and maturity of the child" does not translate to full autonomy for children. ${ }^{87}$ Fortin explains that while article 12 promotes children's capacity for self-determination and autonomy, it does not follow that children have the right to have their decisions implemented. In Fortin's view, children have the right to have their capacity for autonomy promoted and to be consulted, but they do not necessarily have the right to have their views acted upon. ${ }^{88}$

Another important provision of the Convention is article 5, which requires state parties to "respect the responsibilities, rights and duties of parents ... to provide, in a manner consistent with the evolving capacities of the child, appropriate direction and guidance in the exercise by the child of the rights recognized in the ... Convention". 89

When dealing with article 5, the Committee on the Rights of the Child explains as follows: ${ }^{90}$

85 Sloth-Nielsen 1995 SAJHR 410.

86 Committee on the Rights of the Child General Comment No 12: The Right of the Child to be Heard (CRC/C/GC/12 20 July 2009) (hereafter General Comment 12) para [29].

87 Sloth-Nielsen 1995 SAJHR 403; Barratt 2002 THRHR 557-558; Fortin Children's Rights 21-22.

88 Fortin Children's Rights 22 (Fortin's emphasis).

89 Emphasis added.

90 General Comment 12 para [84] (emphasis added). 


\begin{abstract}
The child has a right to direction and guidance, which have to compensate for the lack of knowledge, experience and understanding of the child and are restricted by his or her evolving capacities ... The more the child himself or herself knows, has experienced and understands, the more the parent, legal guardian or other persons legally responsible for the child have to transform direction and guidance into reminders and advice and later to an exchange on an equal footing.
\end{abstract}

In conclusion, the Convention does not expressly afford children with a certain level of maturity the right to independent decision-making. However, I am of the view that this right can be derived from article 12 read with article 5 of the Convention. In my view the obligation in article 12 to give the views of the child due weight in accordance with the child's age and maturity sometimes requires more than mere consultation. This view is strengthened by the obligation placed upon the state in article 5 to recognise the fact that children have evolving capacities, and that the direction and guidance given to them should reflect this fact. Of course, in cases where the child is less mature, his or her participation in decision-making will inevitably take the form of mere consultation. However, if it is found that a child is of such an age and maturity that he or she is capable of making independent decisions, that child should be allowed to make decisions without the consent of his or her parent, and even veto the decisions of his or her parent. One cannot say that the views of a child have been given due weight if mature children are not allowed to influence the outcome of a decision.

\title{
5.2 The African Charter on the Rights and Welfare of the Child 1990
}

On 11 July 1990 the Organisation of African Unity Assembly adopted the African Charter on the Rights and Welfare of the Child ("the Charter") as a regional pendant to the United Nations Convention on the Rights of the Child. ${ }^{91}$ On a political level, this stemmed from a perception of the marginalisation of African states in the drafting process of the Convention. ${ }^{92}$ The Charter provides that in all actions concerning children, the best interests of the child "shall be the primary consideration", ${ }^{93}$ (in contrast to the Convention, which requires the best interests of the child to be "a primary consideration"). ${ }^{94}$ The wording of the Charter may be interpreted to mean that the best interests of the child weigh heavier than other competing rights, suggesting that the protection afforded by the Charter is stronger than the protection afforded by the Convention.

\footnotetext{
91 South Africa ratified the Charter on 7 January 2007.

92 Viljoen "African Charter on the Rights and Welfare of the Child" 335.

93 Article 4(1) of the African Charter on the Rights and Welfare of the Child (1990) (hereafter the Charter).

94 Article 3 (emphasis added) of the Charter. Also see para 5.1 above.
} 
Article 4(2) of the Charter protects children's right to participation:

In all judicial or administrative proceedings affecting a child who is capable of communicating his/her own views, an opportunity shall be provided for the views of the child to be heard either directly or through an impartial representative as a party to the proceedings, and those views shall be taken into consideration by the relevant authority in accordance with the provisions of appropriate law.

The protection of children's participation rights in article 4(2) should be read with article 7, which protects children's freedom of expression. Children who are capable of communicating their own views are afforded the right to express those opinions freely in all matters, and to disseminate their opinions subject to restrictions prescribed by laws.

Du Toit points out that the protection of the child's right to participation in the Charter is both stronger and weaker than the protection in the Convention. ${ }^{95}$ The Charter allows all children who are capable of communicating views to participate. The weight to be attached to the views of the child does not depend on the child's age, maturity and stage of development, as it does in the Convention. ${ }^{96}$ If these facts are considered, it can be concluded that the Charter offers stronger protection than the Convention. ${ }^{97}$

However, in terms of the Charter the child's participation is limited to "judicial and administrative proceedings" affecting the child, in contrast to the Convention's protection "in all matters affecting the child". ${ }^{98}$ This points to a conclusion that the Convention offers stronger protection than the Charter. ${ }^{99}$ Another phrase in article 4(2) points to weaker protection than that offered by the Convention: "[the child's] views will be taken into consideration in accordance with the provisions of appropriate law" (emphasis added). This drawback clause gives states a discretion to limit the right. ${ }^{100}$

A further strong point of the Charter is the provision that the child should be given the opportunity to express his or her views "either directly or through an impartial representative as a party to the proceedings". ${ }^{101}$ This phrase indicates that the child is regarded as an active participant in the proceedings.

\footnotetext{
95 Du Toit "Legal Representation of Children" 110. Also see Kruger 2018 SALJ 81.

$96 \quad$ Article $12(1)$ of the Charter.

97 Du Toit "Legal Representation of Children" 110.

98 Article 12(1) of the Charter.

99 Du Toit "Legal Representation of Children" 110.

100 Gose African Charter 127.

101 Emphasis added.
} 


\subsection{The Constitution of the Republic of South Africa, 1996}

The Constitution contains a section that deals specifically with the protection of children (section 28). Apart from the special protection provided to all children in section 28 , children are entitled to all the fundamental rights conferred on "everyone" in the Constitution. ${ }^{102}$

Section 9, for example, guarantees the right to equality before the law and to the equal protection and benefit of the law, and sections 9(3) and 9(4) prohibit unfair discrimination by the state and by private entities on a nonexclusive list of grounds. As "age" is one of the listed grounds on which unfair discrimination is prohibited, any distinction between children and others based on their age will be scrutinised to determine whether it complies with the prohibition on unfair discrimination.

Currie and De Waal correctly point out that age differs from most of the other grounds of discrimination as it does not refer to an unchanging characteristic - age changes constantly throughout the course of one's life. The burdens and benefits of age differentiation are shared across the entire population every person is at some point in his or her life subject to age restrictions on driving, voting or drinking alcohol, for example. ${ }^{103}$

The Constitution does not confer a right to individual self-determination on children. Children must, like everyone else, derive their claims to personal autonomy from the rights to dignity, ${ }^{104}$ privacy, ${ }^{105}$ and freedom of religion, ${ }^{106}$ expression, ${ }^{107}$ and association. ${ }^{108}$ The interests of children in maintaining their own autonomy must be seen against the background of the relationship of dependence that necessarily exists between parent and child. The responsibilities of care and support of a parent towards a child limit a child's claims to his or her self-determination. If these rights are limited by the exercise of parental authority, this limitation can be justified by the parent's duty of care and support towards the child. However, as the child grows older and the duty of care and support diminishes, it will become

102 Teddy Bear Clinic for Abused Children v Minister of Justice and Constitutional Development 20142 SA 168 (CC) para [38]. The right to vote and the right to stand for or hold public office are not applicable to children, as these rights are expressly afforded to "every adult citizen" in s 19(3) of the Constitution of the Republic of South Africa, 1996 (hereafter the Constitution).

103 Currie and De Waal Bill of Rights Handbook 233-234.

104 Section 10 of the Constitution.

105 Section 14 of the Constitution.

106 Section 15 of the Constitution.

107 Section 16 of the Constitution.

108 Section 17 of the Constitution. See further Currie and De Waal Bill of Rights Handbook 601; Christian Lawyers Association v Minister of Health (Reproductive Health Alliance as Amicus Curiae) 20051 SA 509 (T). Also see Ngwena 1996 Acta Juridica 146. 
progressively more difficult to justify an infringement of the child's personal autonomy. ${ }^{109}$

In terms of section 28(2) "[a] child's best interests are of paramount importance in every matter concerning the child". Section 28(2) has become a key principle in Bill of Rights jurisprudence. It has been used to develop the meaning of some of the other rights in the Bill of Rights, such as the right to family or parental care, ${ }^{110}$ and the right to housing or shelter, ${ }^{111}$ to name but a few. ${ }^{112}$ It has also been used to determine the ambit of, ${ }^{113}$ and to limit, ${ }^{114}$ other competing rights. ${ }^{115}$

The Constitutional Court has provided clear guidelines on the interpretation of section 28(2). In S v M (Centre for Child Law as Amicus Curiae) ${ }^{116}$ Sachs $\mathrm{J}$ held that section 28(2) is not an "overbearing and unrealistic trump" that will automatically assume dominance over other rights. In the words of Sachs J: ${ }^{117}$

$[T]$ he fact that the best interests of the child are paramount does not mean that they are absolute. Like all rights in the Bill of Rights their operation has to take account of their relationship to other rights, which might require that their ambit be limited.

The court therefore confirmed its earlier decision in Minister of Welfare and Population Development $v$ Fitzpatrick that section 28(2) is a right in itself, ${ }^{118}$ which is capable of limitation like all other rights. ${ }^{119}$

Heaton argues that the position of each child should be evaluated in an individualised and contextualised manner when the best interests of the

109 Bekink and Brand "Constitutional Protection of Children" 178.

110 Bannatyne v Bannatyne 20032 SA 363 (CC); S v M (Centre for Child Law as Amicus

Curiae) 20083 SA 232 (CC) (hereafter S v M). Also see Skelton "Constitutional

Protection of Children's Rights" 346.

111 Government of the Republic of South Africa v Grootboom 20011 SA 46 (CC).

112 See further Skelton "Constitutional Protection of Children's Rights" 346-347.

113 De Reuck v Director of Public Prosecutions (Witwatersrand Local Division) 20033

SA 389 (W).

114 Sonderup v Tondelli 20011 SA 1171 (CC).

115 Skelton "Constitutional Protection of Children's Rights" 346.

116 S v M (Centre for Child Law as Amicus Curiae) 20083 SA 232 (CC).

$117 \quad S \vee M$ para [26].

118 Minister of Welfare and Population Development v Fitzpatrick 20003 SA 422 (CC) para [17].

119 In terms of $s$ 36(1) of the Constitution, all rights in the Bill of Rights may be limited by law of general application, if the limitation is reasonable and justifiable in an open and democratic society based on human dignity, equality and freedom. The factors to be taken into account when deciding whether the limitation complies with this test are the nature of the right, the importance of the purpose of the limitation, the nature and extent of the limitation, the relation between the limitation and its purpose, and the existence of less restrictive means to achieve the purpose. 
child criterion is applied. In this evaluation, the impact of each relevant factor on the child should be taken into consideration. ${ }^{120}$ This approach was followed by Sachs $\mathrm{J}$ in $S \vee M$ when he held that "[a] truly principled childcentred approach required a close and individualised examination of the precise real-life situation of the particular child involved". ${ }^{121}$

In my view an approach that recognises the evolving capacities of children and allows children who have the required level of maturity to make independent decisions is in line with this individualised, contextualised, child-centred approach to the application of the best interests of the child criterion. An approach like this recognises that it is in the best interests of a particular child to be protected against his or her own immaturity, but also that the best interests of the child criterion dictates that children who have the required level of maturity should be allowed to make independent decisions. If this approach is followed to its logical consequences, it would mean that a child who is capable of making independent decisions should be allowed to make decisions that appear to be contrary to his or her best interests, such as refusing medical treatment, by the same token that any adult is allowed to make decisions like these.

\section{The extent to which children's right to self-determination is protected in certain medical decisions in South African law}

\subsection{General}

The Children's Act contains provisions that protect children's right to participate in a variety of contexts. ${ }^{122}$ However, none of these provisions goes as far as affording children who possess a certain level of maturity a right to individual self-determination.

One of the general principles of the Children's Act is that both a child and a person who has parental responsibilities and rights in respect of that child must be informed of any action or decision taken in a matter concerning the child which significantly affects the child. ${ }^{123}$ This protection is afforded to a child "having regard to his or her age, maturity and stage of development." The obligation to inform children and persons with parental responsibilities and rights in this subsection arises only "where appropriate".

\footnotetext{
$120 \quad$ Heaton 2009 JJS 1.

$121 \quad S$ v M para [24]. Also see Heaton 2009 JJS 5.

122 On children's rights to participate in certain medical decisions, see Kruger $2018 S A L J$ 73-100.

123 Section 6(5) of the Children's Act.
} 
Section 13 affords every child the right to information on health care. This includes information on health promotion and the prevention and treatment of ill-heath and disease; information on sexuality and reproduction; ${ }^{124}$ information regarding the child's health status; ${ }^{125}$ and information regarding the causes and treatment of the child's health status. ${ }^{126}$ The child is also entitled to confidentiality regarding his or her health status, or the health status of a parent, care-giver or family member, except when it will not be in the best interests of the child to maintain confidentiality. ${ }^{127}$ This information must be relevant and conveyed in a format accessible to children. Due consideration must be given to the needs of disabled children. ${ }^{128}$

Children may participate in an appropriate way in all matters concerning them, and any views expressed by them must be given due consideration. However, section 10 limits this right to children who are "of such an age, maturity and stage of development as to be able to participate". A person with parental responsibilities and rights in respect of a child must give due consideration to any views and wishes expressed by the child before making a list of specified decisions involving the child, bearing in mind the child's age, maturity and stage of development. ${ }^{129}$ The relevant decisions are those listed in section 18(3)(c) - decisions in respect of consent to the child's marriage, adoption, departure or removal from the Republic, application for a passport, and alienation or encumbrance of any immovable property of the child. ${ }^{130}$ It also includes decisions affecting contact between the child and a co-holder of parental responsibilities and rights; decisions regarding the assignment of guardianship or care in respect of the child to another person in terms of section 27; or decisions which are likely to significantly change or have an adverse effect on the child's living conditions, education, health, personal relations with a parent or family member, or the child's general well-being. ${ }^{131}$

The Children's Act strengthens the best interests of the child criterion entrenched in section 28(2) of the Constitution by providing that in all matters concerning the care, protection and well-being of children the standard that the child's best interest is of paramount importance must be

\footnotetext{
124 Section 13(1)(a) of the Children's Act.

125 Section $13(1)(b)$ of the Children's Act.

126 Section 13(1)(c) of the Children's Act.

127 Section 13(1)(d) of the Children's Act.

128 Section 13(2) of the Children's Act.

129 Section 31(1)(a) of the Children's Act. Article 31 is entitled "Major decisions involving child".

130 Section $31(1)(b)(\mathrm{i})$ read with s $18(3)(c)$ of the Children's Act..

131 Section 31(1)(b)(ii)-(iv) of the Children's Act.
} 
applied. ${ }^{132}$ Section $7(1)$ contains a list of factors to be taken into consideration when a provision of the Act requires the best interests of the child standard to be applied. One of the factors to be taken into consideration is the child's age, maturity and stage of development. ${ }^{133}$

\subsection{Medical treatment and operations}

The predecessor of the Children's Act was the Child Care Act 74 of 1983. Until the commencement of section 129 of the Children's Act on 1 April 2010, the Child Care Act allowed a person over the age of 14 years to consent to the performance of the medical treatment of himself or herself without the assistance of his or her parent or guardian. ${ }^{134}$ The Child Care Act did not require an assessment of the child's maturity - compliance with the age requirement of 14 years was sufficient. The Children's Act lowered the age for consent to medical treatment to 12 years, but added a subjective maturity assessment. The Act provides that a child may consent to his or her own medical treatment or the medical treatment of his or her child if the child is over the age of 12 years and is of sufficient maturity and possesses the mental capacity to understand the benefits, risks, social and other implications of the treatment. ${ }^{135}$ The child's parent, guardian or caregiver may consent to the child's medical treatment if the child is under the age of 12 years, or over that age but of insufficient maturity, or is unable to understand the benefits, risks and social implications of the treatment. ${ }^{136}$ This subsection is subject to section 31, which provides that, depending on the age, maturity and stage of development of the child, a person holding parental responsibilities and rights in respect of that child must give due consideration to any views and wishes expressed by the child before taking any decision which is likely to significantly change or have an adverse effect on the child's health. ${ }^{137}$

The Children's Act does not define "medical treatment". However, the concept is interpreted as "non-invasive and innocuous procedures". "Medical treatment" includes vaccinations and psychological treatment. ${ }^{138}$ It also includes receiving blood or blood products. ${ }^{139}$

As far as consent to operations is concerned, the Child Care Act previously allowed any person over the age of 18 years to consent to the performance

\footnotetext{
132 Section 9 of the Children's Act.

133 Section $7(1)(g)(i)$ of the Children's Act.

134 Section 39(4)(a) of the Children's Act.

135 Section 129(2) of the Children's Act.

136 Section 129(4) of the Children's Act.

137 Section 31(1)(a) and 31(1)(b)(iv)) of the Children's Act. Also see para 6.1 above.

138 Mahery, Proudlock and Jamieson Guide to the Children's Act 10; Heaton "Capacity to Perform Juristic Acts: Marriage" 852 n 58. 
of any operation on himself or herself, without the assistance of his or her parent or guardian. ${ }^{140}$ The Children's Act drastically lowered the age of consent to operations to 12 years. However, two additional requirements were added that were not found in the Child Care Act. The first requirement is a subjective maturity assessment, and the second is the requirement that the child must be "duly assisted" by his or her parent or guardian. ${ }^{141}$ The child's parent or guardian may consent to an operation on the child if the child is under the age of 12 years, or over that age but of insufficient maturity, or is unable to understand the benefits, risks and social implications of the operation. ${ }^{142}$ As in the case of consent to medical treatment, this subsection is subject to section 31 .

The regulations contain further prescriptions with regard to the giving of consent to operations by children. The child's consent to an operation must be furnished in writing, and must be completed by the person performing the operation, or by a representative of the institution where the operation is going to be performed. The child must sign the consent form, which must be identical to Form 34. The parent or guardian who duly assists a child to consent to the operation must "assent to this in writing" on the same form. ${ }^{143}$ Part B of the form is entitled "Explanation of nature, consequences, risks and benefits of surgical operation". This part contains a list of the issues that the health-care provider must explain to the child in a manner that is understandable to the child. ${ }^{144}$ The health care provider must also confirm that he or she has given the child an opportunity to ask questions, and that he or she is satisfied that the child is 12 years old or older and of sufficient maturity and has the mental capacity to understand the risks, benefits, social and other implications of the operation. ${ }^{145}$

Part C of Form 34 is entitled "Consent of the child". In this part of the form, the child must confirm in writing that he or she understands that "the following" operation is going to be performed on him or her. Beneath this confirmation, a space is left open where the child must describe the

140 Section 39(4)(b) of the Child Care Act. When the Child Care Act was in operation, the age of majority was still 21 years in terms of $\mathrm{s} 1$ of the Children's Status Act 82 of 1987 . The age of majority was lowered to 18 years on 1 July 2007 by s 17 of the Children's Act.

141 Section 129(3) of the Children's Act.

142 Section 129(5) of the Children's Act.

143 General Regulations Regarding Children, 2010 (GN R261 in GG 33076 of 1 April 2010) reg 48.

144 These are the nature of the problem requiring a surgical operation, the most suitable operation in his or her opinion, any risks associated with the operation, the benefits associated with the operation, any alternative forms of treatment, the social implications of the treatment or operation (if any), and any other implications or consequences of the operation. 
operation in his or her own words. The child also confirms that he or she understands the risks, benefits and possible consequences of the operation that have been explained to him or her. Further, the child confirms that he or she has been given the opportunity to ask questions about his or her condition, alternative forms of treatment, the risks of non-treatment, and the possible consequences of the operation. The child's parent or guardian must also confirm that the child is 12 years old or older and is of sufficient maturity and has the mental capacity to understand the benefits, risks, social and other implications of "the following operation". A space is left blank where the parent or guardian must write the type of surgical operation. The parent or guardian also confirms that he or she has duly assisted the child to furnish consent.

The Children's Act provides for substitute consent to the medical treatment of or the performance of surgical operations on children in certain circumstances. The superintendent of a hospital (or the person in charge of the hospital in the superintendent's absence) may provide consent to medical treatment or operations in certain emergency situations. This substitute consent may be furnished if the treatment or operation is necessary to preserve the child's life or save the child from serious or lasting physical injury or disability, and the need for the treatment or operation is so urgent that the treatment or operation cannot be delayed in order to get the required consent. ${ }^{146}$

The Act also provides for substitute consent if the person responsible for giving consent to medical treatment of or the performance of surgical operations on children refuses to give consent. The minister may consent to the medical treatment or operation if the child's parent or guardian unreasonably refuses to give consent. ${ }^{147}$ The minister may also consent to the medical treatment or operation if the child unreasonably refuses to give consent. ${ }^{148}$ Further, a High Court or children's court may consent to the medical treatment of or performance of an operation on a child in all instances where another person that may give consent refuses or is unable to give such consent. ${ }^{149}$

When a child's guardian is incapable of giving consent (or of assisting the child in giving consent), cannot readily be traced, or is deceased, the minister may consent to the medical treatment of or performance of an operation on the child. ${ }^{150}$

\footnotetext{
146 Section 129(6) of the Children's Act.

147 Section 129(7)(a) of the Children's Act.

148 Section 129(8) of the Children's Act.

149 Section 129(9) of the Children's Act.

150 Section 129(7)(b)-(d) of the Children's Act.
} 
The phrase "duly assisted" is not defined in the Children's Act. As indicated elsewhere, ${ }^{151}$ I share the view held by Himonga and Cooke ${ }^{152}$ that the phrase refers to parental help, for the following reasons. First, the Children's Act provides that parental responsibilities and rights include the responsibility and right to care for the child. ${ }^{153}$ "Care" is defined as including, where appropriate, "guiding, advising and assisting the child in decisions to be taken by the child in a manner appropriate to the child's age, maturity and stage of development". ${ }^{154}$ Secondly, state parties are obliged in terms of the Convention on the Rights of the Child to respect the responsibilities, rights and duties of parents to provide, in a manner consistent with the evolving capacities of the child, appropriate direction and guidance in the exercise by the child of the rights in the Convention. ${ }^{155}$ Thirdly, I am of the view that the phrases "unreasonably refuses to give consent or to assist the child in giving consent" and "incapable of giving consent or of assisting the child in giving consent" in section 129(7) of the Act suggest that there is a difference in meaning between "consent" and "assistance in giving consent". If this interpretation is correct, the use of the term "assistance" in the Children's Act is confusing as it corresponds with the term "assistance" that is used as an umbrella term for the various actions that a guardian can take to supplement a minor's limited capacity to act. ${ }^{156}$ To clear up this confusion, the legislator should replace the phrase "duly assisted" with the phrase "duly directed and guided". ${ }^{157}$

In conclusion, the Children's Act appears to protect the right to selfdetermination of mature minors over the age of 12 years, as these minors may independently consent to medical treatment. However, if the medical practitioner is unsure how maturity should be determined, ${ }^{158}$ it may be easier to conclude that the child lacks the necessary maturity and require consent by the parent or guardian.

The question whether or not the right of mature minors over the age of 12 years to independently consent to surgical operations is protected is a bit

\footnotetext{
$151 \quad$ Kruger 2018 SALJ 94.

152 Himonga and Cooke 2007 IJCR 336. Also see Slabbert 2004 PELJ 171, where she asks the question whether the phrase could possibly refer to "parental advice or supplementary support".

153 Section 18(2)(a) of the Children's Act.

154 See para $(f)$ of the definition of "care" in s 1 of the Children's Act.

155 Article 5 of the United Nations Convention on the Rights of the Child (1989) (emphasis added).

156 Heaton Law of Persons 89. The guardian may act on behalf of the minor, the minor may personally conclude the agreement with the guardian's consent, or the guardian may ratify the agreement after its conclusion.

157 Kruger 2018 SALJ 100.

158 On the lack of expertise or guidelines in assessing children's maturity or informed consent, see Kruger 2018 SALJ 85-86.
} 
more complicated and depends on a number of factors. First, if the medical practitioner interprets the phrase "duly assisted" as meaning that the parent or guardian should provide substitute or supplementary consent, there can be no question of independent decision-making by the mature minor. Secondly, as in the case of consent to medical treatment, the medical practitioner may be unsure how to determine maturity. If medical practitioners do not use forms similar to Form 34, this problem may be compounded. Form 34 is helpful in facilitating the process of obtaining informed consent, as it contains clear guidelines on the issues that must be explained to the child. The form also requires the child to confirm in writing that he or she understands the issues that have been explained by the health care provider.

\section{Conclusion}

The view that children's autonomy should be protected originated in the children's rights movement. The correct approach to the protection of children's rights is a via media approach, like the one advocated by Freeman, in terms of which both the "nurturance" and "self-determination" approaches are followed, depending on the child's level of maturity. ${ }^{159}$ This via media approach is echoed in the Convention, which protects the interests of children and provides for the recognition of their evolving capacities. ${ }^{160}$

The Convention does not provide a very strong legal basis for the protection of children's right to self-determination in medical decision-making. The reason for this is the view held by child law scholars that article 12 does not translate to full autonomy for children. However, if article 12 is read with article 5 (which places an obligation on state parties to recognise the evolving capacities of children), the legal basis for the protection of children's right to self-determination is strengthened. ${ }^{161}$

In contrast to the Convention, the Constitution provides a strong legal basis for the protection of children's right to self-determination. This legal basis is found, first of all, in the equality clause, particularly in the prohibition of unfair discrimination based on age. ${ }^{162}$ Secondly, the legal basis can be found in the right to personal autonomy that is derived from the rights to dignity, ${ }^{163}$

\footnotetext{
159 See para 2 above.

160 See para 5.1 above.

161 See para 5.1 above.

162 Section 9(3) of the Constitution.

163 Section 10 of the Constitution.
} 
privacy, ${ }^{164}$ and freedom of religion, ${ }^{165}$ expression ${ }^{166}$ and association. ${ }^{167}$ Thirdly, the legal basis can be found in an individualised and contextualised application of the best interests of the child criterion, which recognises that it is in the best interests of a child to be protected against his or her own immaturity, but also to allow a child with the required level of maturity to make independent decisions. ${ }^{168}$

The Children's Act ${ }^{169}$ protects children's right to self-determination as far as consent to medical treatment is concerned. This protection will be maximised if medical practitioners are provided with training to assist them in assessing maturity. Elsewhere I have argued that training on ageappropriate communication skills and maturity assessment should be included in the training of all healthcare providers. ${ }^{170}$

The answer to the question if the Children's Act protects the right to selfdetermination of children as far as consent to operations is concerned depends on the interpretation of the phrase "duly assisted" in the Act. ${ }^{171}$ If the phrase is interpreted as requiring the child's parent or guardian to provide direction and guidance, the protection of children's right to selfdetermination will be maximised. For this reason I propose that the phrase "duly assisted" in the Children's Act be replaced with the phrase "duly directed and guided". To maximise the protection of children's right to selfdetermination further, I propose that health care providers should use forms similar to Form $34 .{ }^{172}$

In conclusion, the doctrine of informed consent allows for the recognition of the evolving capacities of children, as children who have the maturity to understand the nature and extent of the harm or risk associated with the medical intervention, including its consequences, may independently consent to the intervention. Section 129 of the Children's Act is aligned with the doctrine of informed consent, as it allows children older than twelve years to independently consent to certain medical interventions, provided they are of sufficient maturity and have the mental capacity to understand the benefits, risks, social and other implications of the intervention.

\footnotetext{
164 Section 11 of the Constitution.

165 Section 15 of the Constitution.

166 Section 16 of the Constitution.

167 Section 18 of the Constitution.

168 See para 5.3 above.

169 See paras 6.1 and 6.2 above.

170 See Kruger 2018 SALJ 100.

171 Section 129(3)(c).

172 See para 6.2 above.
} 


\section{Bibliography}

\section{Literature}

Ariès Centuries of Childhood

Ariès P Centuries of Childhood: A Social History of Family Life (Knopf New York 1962)

Arshagouni 2006 J Health Care L \& Pol'y

Arshagouni P "'But I'm an Adult now ... sort of': Adolescent Consent in Health Care Decision-making and the Adolescent Brain" $2006 \mathrm{~J}$ Health Care L \& Pol'y 315-364

Bainham Children

Bainham A Children: The Modern Law $3^{\text {rd }}$ ed (Family Law Bristol 2005)

Barratt 2002 THRHR

Barratt A "A Child's Right to be Heard in Custody and Access Determinations" 2002 THRHR 556-573

Bekink and Brand "Constitutional Protection of Children"

Bekink B and Brand D "Constitutional Protection of Children" in Davel CJ (ed) et al Introduction to Child Law in South Africa (Juta Lansdowne 2000) 169-196

Binford 2012 Article 40

Binford W "Criminal Capacity and the Teenage Brain: Insights from Neurological Research" December 2012 Article 40 1-6

Blakemore and Choudhury 2006 J Child Psychol Psychiatry

Blakemore $S$ and Choudhury $S$ "Development of the Adolescent Brain: Implications for Executive Function and Social Cognition" $2006 \mathrm{~J}$ Child Psychol Psychiatry 296-312

Boberg Persons and Family

Boberg PQR The Law of Persons and the Family (Juta Cape Town 1977)

Buchanan and Brock Deciding for Others

Buchanan AE and Brock DW Deciding for Others: The Ethics of Surrogate Decision Making (Cambridge University Press Cambridge 1989)

Caufmann and Steinberg 2000 Behav Sci Law

Caufmann $E$ and Steinberg $L$ "( $\mathrm{Im})$ maturity of Judgment in Adolescence: Why Adolescents may be less Culpable than Adults" 2000 Behav Sci Law $741-760$ 
Cockrell "Capacity to Perform Juristic Acts: Contracts"

Cockrell A "Capacity to Perform Juristic Acts: Contracts" in Van Heerden B, Cockrell A and Keightley R (eds) Boberg's Law of Persons (Juta Kenwyn 1999) $756-834$

Coons and Mnookin "Towards a Theory of Children's Rights"

Coons JE and Mnookin RH "Towards a Theory of Children's Rights" in Baxter IFG and Eberts MA (eds) The Child and the Courts (Sweet \& Maxwell London 1978) 391-398

Currie and De Waal Bill of Rights Handbook

Currie I and De Waal J The Bill of Rights Handbook $6^{\text {th }}$ ed (Juta Cape Town 2016)

Delmage 2013 Youth Justice

Delmage $E$ "The Minimum Age of Criminal Responsibility: A Medico-legal Perspective" 2013 Youth Justice 102-110

De Villiers 1993 Stell LR

De Villiers B "The Rights of Children in International Law: Guidelines for South Africa" 1993 Stell LR 289-310

Du Toit "Legal Representation of Children"

Du Toit C "Legal Representation of Children" in Boezaart T (ed) Child Law in South Africa $2^{\text {nd }}$ ed (Juta Claremont 2017) 108-133

Eekelaar 1986 LQR

Eekelaar J "The Eclipse of Parental Rights" 1986 LQR 4-9

Eekelaar 1986 OJLS

Eekelaar "The Emergence of Children's Rights" 1986 OJLS 161-182

Farson Birthrights

Farson RE Birthrights (Macmillan New York 1978)

Fortin Children's Rights

Fortin J Children's Rights and the Developing Law (Butterworths London 1998)

Freeman 1980 CLP

Freeman MDA "The Rights of Children in the International Year of the Child" 1980 CLP 1-31

Freeman 1992 IJLPF

Freeman MDA "Taking Children's Rights more Seriously" 1992 IJLPF 5271 
Freeman 1998 IJCR

Freeman MDA "The Sociology of Childhood and Children's Rights" 1998 IJCR 433-444

Freeman "Limits of Children's Rights"

Freeman MDA "The Limits of Children's Rights" in Freeman MDA and Veerman PE (eds) The Ideologies of Children's Rights (Martinus Nijhoff Dordrercht 1992) 29-46

Freeman Rights and Wrongs

Freeman MDA The Rights and Wrongs of Children (Pinter Dover 1983)

Gose African Charter

Gose M The African Charter on the Rights and Welfare of the Child (Community Law Centre, University of the Western Cape Cape Town 2000)

Grisso and Vierling 1978 Prof Psychol

Grisso T and Vierling L "Minor's Consent to Treatment: A Developmental Perspective" 1978 Prof Psychol 412-427

Hartman 2000 Hastings LJ

Hartman RG "Adolescent Autonomy: Clarifying an Ageless Conundrum" 2000 Hastings LJ 1265-1362

Hartman 2002 AJLM

Hartman RG "Coming of Age: Devising Legislation for Adolescent Medical Decision-making" 2002 AJLM 409-453

Heaton "Capacity to Perform Juristic Acts: Marriage"

Heaton J "Capacity to Perform Juristic Acts: Marriage and other Acts" in Van Heerden B, Cockrell A and Keightley R (eds) Boberg's Law of Persons (Juta Kenwyn 1999) 835-854

Heaton 2009 JJS

Heaton J "An Individualized, Contextualized and Child-centred Determination of the Child's Best Interests, and the Implications of such an Approach in the South African Context" 2009 JJS 1-18

Heaton Law of Persons

Heaton J The South African Law of Persons $5^{\text {th }}$ ed (LexisNexis Durban 2017)

Himonga and Cooke 2007 IJCR

Himonga C and Cooke A "A Child's Autonomy with Special Reference to Reproductive Medical Decision-making in South African Law: Mere Illusion or Real Autonomy?" 2007 IJCR 323-363 
Human 2000 THRHR

Human S "Die Effek van Kinderregte op die Privaatregtelike Ouer-kind Verhouding" 2000 THRHR 393-402

Human 2000 Stell LR

Human S "Kinderregte en Ouerlike Gesag: 'n Teoretiese Perspektief" 2000 Stell LR 71-84

Kruger Judicial Interference with Parental Authority

Kruger JM $(\mathrm{H})$ Judicial Interference with Parental Authority: A Comparative Analysis of Child Protection Measures (LLD-thesis University of South Africa 2003)

Kruger 2006 THRHR

Kruger JM $(\mathrm{H})$ "The Philosophical Underpinnings of Children's Rights Theory" 2006 THRHR 436-453

Kruger 2018 SALJ

Kruger $\mathrm{H}$ "The Realization of Children's Rights to Participate in Selected Medical Decisions in South Africa" 2018 SALJ 73-100

Mahery "Consent Laws"

Mahery $P$ "Consent Laws Influencing Children's Access to Health Care Services" in ljumba P and Padarath A (eds) South African Health Review 2006 (Health Systems Trust Durban 2006) 167-180

Mahery, Proudlock and Jamieson Guide to the Children's Act Mahery P, Proudlock $\mathrm{P}$ and Jamieson $\mathrm{L}$ A Guide to the Children's Act for Health Professionals $4^{\text {th }}$ ed (Children's Institute University of Cape Town 2010)

McCabe 1996 J Pediatr Psychol

McCabe MA "Involving Children and Adolescents in Medical Decision Making: Developmental and Clinical Considerations" $1996 \mathrm{~J}$ Pediatr Psychol 505-516

McQuoid-Mason 2010 SAMJ

McQuoid-Mason D "Termination of Pregnancy and Children: Consent and Confidentiality Issues" 2010 SAMJ 213-214

Neethling and Potgieter Law of Delict Neethling J and Potgieter JM Neethling - Potgieter - Visser Law of Delict $7^{\text {th }}$ ed (LexisNexis Durban 2015) 
Ngwena 1996 Acta Juridica

Ngwena C "Health Care Decision-making and the Competent Minor: The Limits of Self-determination" 1996 Acta Juridica 132-147

Platt Child Savers

Platt AM The Child Savers: The Invention of Delinquency $2^{\text {nd }}$ ed (University of Chicago Press Chicago 1977)

Robinson 1993 TRW

Robinson JA "'n Oorsig oor die Vertrekpunte van die Engelse Children Act 1989" 1993 TRW 41-66

Robinson 2002 Stell LR

Robinson JA "An Introduction to the International Law on the Rights of the Child Relating to the Parent-child Relationship" 2002 Stell LR 309-320

Robinson and Ferreira 2000 De Jure

Robinson JA and Ferreira GM "Die Reg van die Kind om Gehoor te word: Enkele Verkennende Perspektiewe op die VN Konvensie oor die Regte van die Kind (1989)" 2000 De Jure 54-67

Scott, Reppucci and Woolard 1995 Law \& Hum Behav

Scott ES, Reppucci ND and Woolard JL "Evaluating Adolescent Decisionmaking in Legal Contexts" 1995 Law \& Hum Behav 221-244

Skelton "Constitutional Protection of Children's Rights"

Skelton A "Constitutional Protection of Children's Rights" in Boezaart T (ed) Child Law in South Africa $2^{\text {nd }}$ ed (Juta Claremont 2017) 327-358

Slabbert 2004 PELJ

Slabbert MN "Parental Access to Minor's Health Records in the South African Health Care Context: Concerns and Recommendations" 2004 PELJ 165-184

Sloth-Nielsen 1995 SAJHR

Sloth-Nielsen $\mathrm{J}$ "Ratification of the United Nations Convention on the Rights of the Child: Some Implications for South African Law" 1995 SAJHR 401420

Spear Behavioral Neuroscience of Adolescence

Spear LP The Behavioral Neuroscience of Adolescence (Norton New York 2010)

Steinberg Adolescence

Steinberg LD Adolescence $3^{\text {rd }}$ ed (McGraw-Hill New York 1993) 
Steinberg and Meyer Childhood

Steinberg L and Meyer R Childhood (McGraw-Hill New York 1995)

Strauss Doctor, Patient and the Law

Strauss S Doctor, Patient and the Law $3^{\text {rd }}$ ed (Van Schaik Hatfield 1991)

Thomas 2007 SALJ

Thomas R "Where to from Castell $v$ De Greef? Lessons from Recent Developments in South Africa and Abroad regarding Consent to Treatment and the Standard of Disclosure" 2007 SALJ 188-215

Van Bueren "United Nations Convention on the Rights of the Child" Van Bueren G "The United Nations Convention on the Rights of the Child" in Davel CJ (ed) et al Introduction to Child Law in South Africa (Juta Lansdowne 2000) 210-212

Van Oosten Doctrine of Informed Consent

Van Oosten FFW The Doctrine of Informed Consent in Medical Law (LLD thesis University of South Africa 1989)

Viljoen "African Charter on the Rights and Welfare of the Child"

Viljoen $\mathrm{F}$ "The African Charter on the Rights and Welfare of the Child" in Boezaart T (ed) Child Law in South Africa (Juta Claremont 2009) 331-350

Wald 1979 UCDLR

Wald MS "Children's Rights: A Framework for Analysis" 1979 UCDLR 255282

WHO Health of Young People

World Health Organisation The Health of Young People: A Challenge and a Promise (WHO Geneva 2013)

\section{Case law}

Bannatyne v Bannatyne 20032 SA 363 (CC)

Castell v De Greeff 19944 SA 408 (C)

Christian Lawyers Association v Minister of Health (Reproductive Health Alliance as Amicus Curiae) 20051 SA 509 (T)

De Reuck v Director of Public Prosecutions (Witwatersrand Local Division) 20033 SA $389(\mathrm{~W})$

Gillick $v$ West Norfolk and Wisbech Area Health Authority and the DHSS 19853 All ER 402 
Government of the Republic of South Africa v Grootboom 20011 SA 46 (CC)

Minister of Welfare and Population Development v Fitzpatrick 20003 SA 422 (CC)

Roper v Simmons 543 US 551 (2005)

S v M (Centre for Child Law as Amicus Curiae) 20083 SA 232 (CC)

Sonderup v Tondelli 20011 SA 1171 (CC)

Teddy Bear Clinic for Abused Children $v$ Minister of Justice and Constitutional Development 20142 SA 168 (CC)

\section{Legislation}

Age of Majority Act 57 of 1972

Child Care Act 74 of 1983

Children's Act 38 of 2005

Children's Status Act 82 of 1987

Choice on Termination of Pregnancy Act 92 of 1996

Constitution of the Republic of South Africa, 1996

General Regulations Regarding Children, 2010 (GN R261 in GG 33076 of 1 April 2010)

National Health Act 61 of 2003

International instruments

African Charter on the Rights and Welfare of the Child (1990)

Committee on the Rights of the Child General Comment No 12: The Right of the Child to be Heard (CRC/C/GC/12 20 July 2009)

United Nations Convention on the Rights of the Child (1989)

\section{List of Abbreviations}

AJLM

Behav Sci Law
American Journal of Law and Medicine

Behavioral Sciences and the Law 


$\begin{array}{ll}\text { CLP } & \text { Current Legal Problems } \\ \text { Hastings LJ } & \text { Hastings Law Journal } \\ \text { IJCR } & \text { International Journal of Children's Rights } \\ \text { IJLPF } & \text { International Journal of Law, Policy and the } \\ & \text { Family } \\ \text { J Child Psychol Psychiatry } & \text { Journal of Child Psychology and Psychiatry } \\ \text { J Health Care L \& Pol'y } & \text { Journal of Health Care Law and Policy } \\ \text { J Pediatr Psychol } & \text { Journal of Pediatric Psychology } \\ \text { JJS } & \text { Journal for Juridical Science } \\ \text { Law \& Hum Behav } & \text { Law and Human Behavior } \\ \text { LQR } & \text { Law Quarterly Review } \\ \text { OJLS } & \text { Oxford Journal of Legal Studies } \\ \text { PELJ } & \text { Potchefstroom Electronic Law Journal } \\ \text { Prof Psychol } & \text { Professional Psychology } \\ \text { SAJHR } & \text { South African Journal on Human Rights } \\ \text { SALJ } & \text { South African Law Journal } \\ \text { SAMJ } & \text { South African Medical Journal } \\ \text { Stell LR } & \text { Stellenbosch Law Review } \\ \text { THRHR } & \text { Tydskrif vir Hedendaagse Romeins- } \\ & \text { Hollandse Reg (Journal of Contemporary } \\ \text { TRW } & \text { Roman-Dutch Law) } \\ \text { UCDLR } & \text { Tydskrif vir Regswetenskap } \\ \text { WHO } & \text { University of California, Davis Law Review } \\ & \text { World Health Organisation } \\ \end{array}$

